46 (1) | 2017

La orfebrería en los Andes en la época inca (siglos XV$\mathrm{XVI})$

\title{
Product of the art market? The representation of silver corncobs at the Ethnologisches Museum in Berlin
}

¿Producto del mercado de arte? La representación de mazorcas de maíz de plata en el Ethnologisches Museum de Berlin

Produit du marché de l'art? La représentation d'épis de maïs en argent au Ethnologisches Museum de Berlin

Manuela Fischer, Stefan Röhrs, Elena Gómez-Sánchez, Regine-Ricarda Pausewein, Hermann Born, Ina Reiche and Kai Engelhardt

\section{OpenEdition}

Journals

Electronic version

URL: http://journals.openedition.org/bifea/8301

DOI: 10.4000/bifea.8301

ISSN: 2076-5827

\section{Publisher}

Institut Français d'Études Andines

\section{Printed version}

Date of publication: 1 April 2017

Number of pages: 291-305

ISSN: 0303-7495

\section{Electronic reference}

Manuela Fischer, Stefan Röhrs, Elena Gómez-Sánchez, Regine-Ricarda Pausewein, Hermann Born, Ina Reiche and Kai Engelhardt, «Product of the art market? The representation of silver corncobs at the Ethnologisches Museum in Berlin », Bulletin de l'Institut français d'études andines [Online], 46 (1) | 2017, Online since 08 April 2017, connection on 06 November 2020. URL : http://journals.openedition.org/ bifea/8301 ; DOI : https://doi.org/10.4000/bifea.8301

Les contenus du Bulletin de l'Institut français d'études andines sont mis à disposition selon les termes de la licence Creative Commons Attribution - Pas d'Utilisation Commerciale - Pas de Modification 4.0 International. 


\title{
Product of the art market? The representation of silver corncobs at the Ethnologisches Museum in Berlin
}

\author{
Manuela Fischer* \\ Stefan Röhrs** \\ Elena Gómez-Sánchez ${ }^{* * *}$ \\ Regine-Ricarda Pausewein ${ }^{* * *}$ \\ Hermann Born ${ }^{* * * * *}$ \\ Ina Reiche ${ }^{* * * * * *}$ \\ Kai Engelhardt
}

\begin{abstract}
In the 1960s two similar silver corncobs attributed to the Chimú-Inca period were sold by New York based art dealers to the Museum für Völkerkunde in Berlin, now the Ethnologisches Museum, and to the Denver Art Museum. The composition of the Berlin piece shows the use of different alloys,
\end{abstract}

* $\quad$ Ethnologisches Museum, Staatliche Museen zu Berlin, Preußischer Kulturbesitz, Berlin, Germany. E-mail: m.fischer@smb.spk-berlin.de

** Staatliche Museen zu Berlin, Stiftung Preußischer Kulturbesitz, Rathgen-Forschungslabor, Berlin, Germany. E-mail: s.roehrs@smb.spk-berlin.de

*** Deutsches Bergbau-Museum, Bochum, Germany. E-mail: elena.gomezsanchez@bergbaumuseum.de

**** Staatliche Museen zu Berlin, Stiftung Preußischer Kulturbesitz, Rathgen-Forschungslabor, Berlin, Germany. E-mail: r.pausewein@smb.spk-berlin.de

***** Museum für Vor- und Frühgeschichte, Staatliche Museen zu Berlin, Germany. E-mail: h.born@ smb.spk-berlin.de

****** Staatliche Museen zu Berlin, Stiftung Preußischer Kulturbesitz, Rathgen-Forschungslabor, Berlin, Germany. E-mail: i.reiche@smb.spk-berlin.de

${ }^{* * * * * * *}$ Ethnologisches Museum, Staatliche Museen zu Berlin, Preußischer Kulturbesitz, Berlin, Germany. E-mail: k.engelhardt@smb.spk-berlin.de 
suggesting the reuse of different pre-Columbian objects. Only the hard-solders used to join the different parts of the corncobs contain an amount of zinc that might indicate a modern intervention. The hypothesis of this article is that economic stability in the 1960s combined with the desire to restore Second World War losses in museums collections particularly in Germany paved the way for doubtable purchases including forgeries.

Keywords: metallurgy, silver, miniature, forgery, Robert Stolper, Ethnologisches Museum

\title{
¿Producto del mercado de arte? La representación de mazorcas de maíz de plata en el Ethnologisches Museum de Berlin
}

\section{Resumen}

En los años 1960 dos mazorcas de maíz similares, hechas en plata, atribuidas al período chimú-inca han sido vendidas por dos comerciantes de arte de Nueva York al Museum für Völkerkunde, hoy Ethnologisches Museum, de Berlín, y al Denver Art Museum. La composición de las dos piezas muestra el uso de diferentes aleaciones, lo que sugiere la reutilización de diferentes objetos precolombinos. Solo las soldaduras utilizadas para unir las diferentes partes de las mazorcas contienen una cantidad de zinc que podría indicar una intervención moderna. La hipótesis de este artículo es que la estabilidad económica en la década de 1960 combinada con el deseo de restablecer las pérdidas de la Segunda Guerra Mundial en colecciones de museos, especialmente en Alemania, facilitó el camino para compras dudosas incluyendo falsificaciones.

Palabras clave: metalurgia, plata, miniaturas, falsificación, Robert Stolper, Ethnogisches Museum

\section{Produit du marché de l'art ? La représentation d'épis de maïs en argent au Ethnologisches Museum de Berlin}

\begin{abstract}
Résumé
Pendant les années 1960, deux représentations d'épis de maïs en argent, semblables, considérées comme chimú-inca, ont étés vendues à Berlin au Museum für Völkerkunde, aujourd'hui Ethnologisches Museum, et au Denver Art Museum, par deux marchands d'art new yorkais. La composition des deux pièces montre l'utilisation de différents alliages, ce qui suggère la réutilisation de plusieurs objets précolombiens. Seul, l'alliage utilisé pour joindre les différentes parties de l'épi de maïs par brasure contient une quantité de zinc qui fait penser à une intervention moderne. L'hypothèse de cet article est que la stabilité économique des années 1960 et la volonté de rétablir les pertes causées par la Seconde Guerre Mondiale dans les collections des musées, particulièrement en Allemagne, ont contribué à l'achat d'objets d'art d'authenticité douteuse et même de faux.
\end{abstract}

Mots-clés : métallurgie, argent, miniature, faux, Robert Stolper, Musée ethnologique

\section{INTRODUCTION}

While conducting his research on Incan miniatures and their function within the Inca state for his PhD thesis, "Scale and the Incas", Andrew Hamilton got aware of a representation of a corn plant with two cobs made of metal sheets at the 
Ethnologisches Museum in Berlin1. The relatively large size of the object (with a length of $25.7 \mathrm{~cm}$ and a width of $7 \times 9 \mathrm{~cm})^{2}$ is reminiscent of the descriptions found in Spanish chronicles of the plants and animals in natural size from the garden of the sun in Coricancha, the center of the Inca state in Cuzco, but none survived colonial times. In fact, there are only two similar objects of this kind reported worldwide, the one in Berlin (Fig. 1) and the other at the Denver Art Museum³ (Fig. 2).
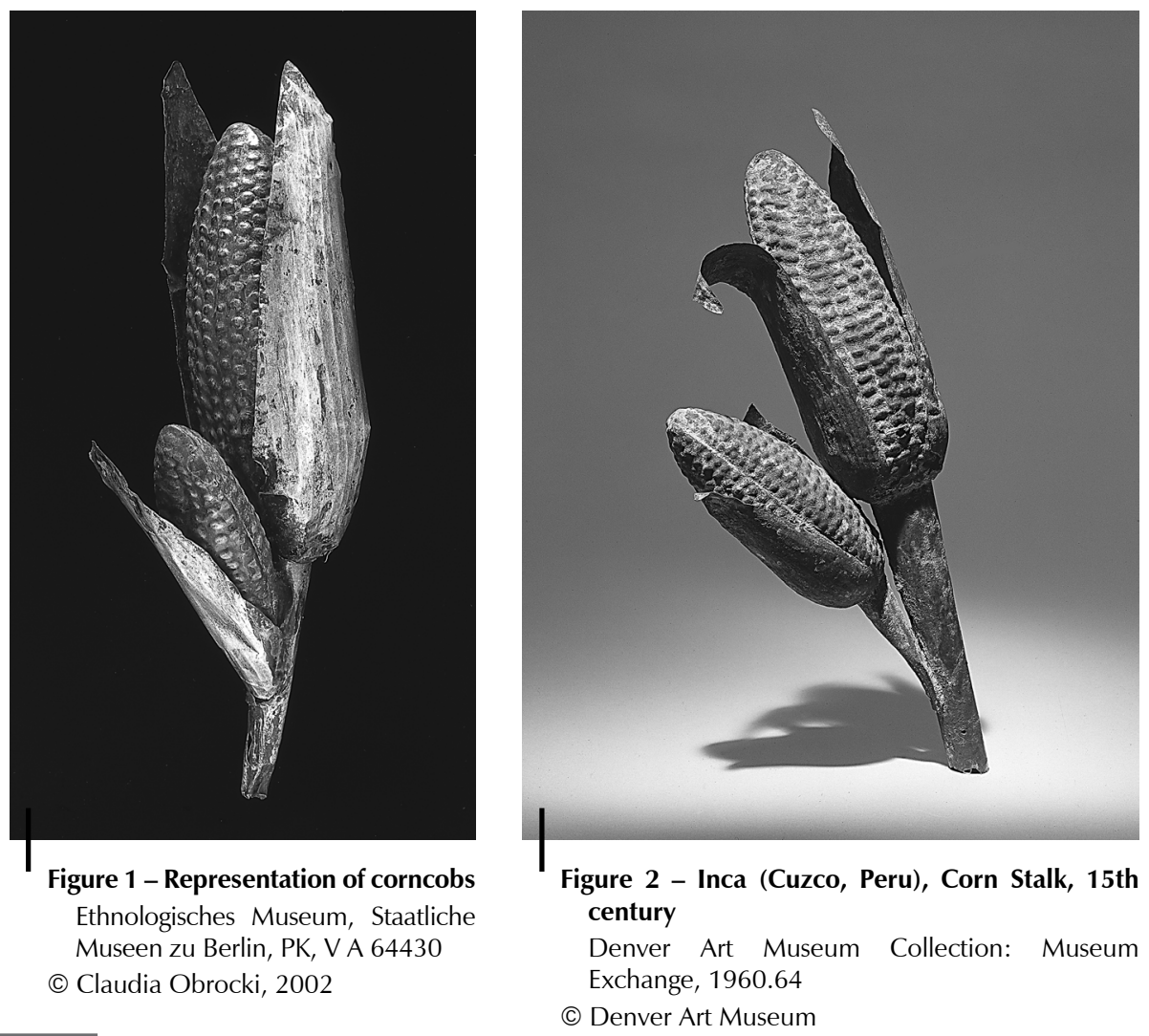

1 The Ph. D. thesis was submitted at Princeton University, where Andrew Hamilton is currently preparing the book manuscript "Scale and the Incas".

2 The weight is 79 grams.

3 A third representation of a corn cob hosted at the Mint Museum, Charlotte (North Carolina, USA) is different in shape and material and will not be referred to in this paper. We want to thank Jonathan Stuhlman for the research he did on the provenance: "The corn cob effigy had been on loan to us since the 1980s and was formally donated in 2008. It came from a private collection; the collector lived nearby but also spent a great deal of time in Italy and London; I did not see anything in the files indicating that we knew more about its provenance". Email Jonathan Stuhlman to Manuela Fischer, 31. 8. 2015. Available in http://www.mintmuseum.org/?open_collection $=\% 2$ Fresources $\% 2$ Fcollection-database\%2Fitem\%2F2008.81.7\%2Fmaize-cob-effigy\%2F Inventory no. 2008.81.7, gift of William and Mary Barnes. The place where the object was created is indicated with: "Southern Highlands". 
They are unique because of their size, and their naturalistic representation. Hamilton initiated an extensive analysis. Several institutions contributed to this research: the Ethnologisches Museum and the laboratory of the Staatliche Museen zu Berlin, the Rathgen-Forschungslabor, dedicated to the analysis of cultural heritage objects and conservation science ${ }^{4}$, the Denver Art Museum in Denver, Colorado and The School of Mines in Golden, Colorado.

Through the research it became clear that the authenticity of the objects had already been debated, after a picture of the Berlin piece was published in 1966 and in an English translation in 1967 of the "Daily Life in Ancient Peru"? (Disselhoff, 1966; 1967)5. The curator of the pre-Columbian collection at the Denver Art Museum, Robert Stroessner, became curious about the object in Berlin. Nevertheless he didn't accept the arguments questioning the authenticity of the Denver piece. As he explains in a letter directed to Dieter Eisleb, curator at the Museum für Völkerkunde in Berlin:

We have nearly an identical pair of "corncobs" in our collection, which is being questioned by American experts. The only explanation being "no known examples of this type have survived with collection history or excavation history". Thus I am hoping we can prove both pieces are authentic6.

The curator of the South American Archaeology at the Museum of Natural History in New York, Junius Bird, however, was quite convinced that the Berlin representation of corncobs was a fake. Bird emphasized mainly two aspects, which, to him, seemed to be indications for a falsification: the technique - the patina and artificial corrosion - and the botanical rendering.

In the correspondence with the museum in Berlin, dated December 30th, 1968, Junius Bird also reminds us that at the end of the 1940s

[...] some metal workers in Lima made a number of these in gold, silver and copper which were then sold as genuine antiquities. In addition to technical details, which revealed their modern origin (artificial patina, simulated breakage and corrosion, etc.), they were characterized by botanically inconsistent detail or errors of observation, which I am sure no pre-Spanish artisan would have committed. In most cases the ears are shown partially stripped of husks and with incorrect depiction of kernel row termination. Some also have far more rows of kernels than any corn ear ever had. In one instance, when a nearly complete corn plant was shown, the ear was at the top where the tassel should $\mathrm{be}^{7}$.

4 See also Howard 1968 and the early publication of the purchase by Disselhoff 1961a; $1961 \mathrm{~b}$.

5 The text refers to a report by the Rathgen-Forschungslabor No. B-74_082812 with contributions by Stefan Röhrs, Elena Gómez Sánchez, Regine-Ricarda Pausewein, Hermann Born and Ina Reiche.

6 Letter from Robert J. Stroessner, Denver Colorado, USA, January $13^{\text {th }}, 1969$ to Dieter Eisleb, curator of the pre-Columbian collection at the Museum für Völkerkunde, Staatliche Museen zu Berlin. New World Department Archive Denver Art Museum, provided by Andrew Hamilton.

7 Letter from Junius B. Bird, Curator of South American Archaeology, December 30th, 1968 to Dieter Eisleb, Staatliche Museen zu Berlin, Museum für Völkerkunde, Abteilung Amerikanische Archäologie, Berlin. New World Department Archive Denver Art Museum, provided by Andrew Hamilton. 
There is obviously certain clumsiness in the representation of the plant (compare Fig. 3), as there are very sophisticated objects made of gold and silver sheets from the Chimú, from the north coast of Peru (Cordy-Collins, 1996). The provenance given by the art dealer, Robert L. Stolper, was in fact Chimú, a center for silversmiths since pre-Inca times. The object was bought by Hans Dietrich Disselhoff, head of the department of American archeology and director of the then Museum für Völkerkunde for 850 \$, which equated 3,400 DM in 1961".

In the first illustration published in "Alltag im alten Peru" 1966 by Hans Dietrich Disselhoff, the corncobs still show "gilded leaves" (Fig. 4). The reddish-golden color as well as the blackish patina nearly disappeared, probably after a cleaning, which is however not reported in the museum files. The Berlin piece today shows a metallic silver color with some blackish and greenish corrosion products on

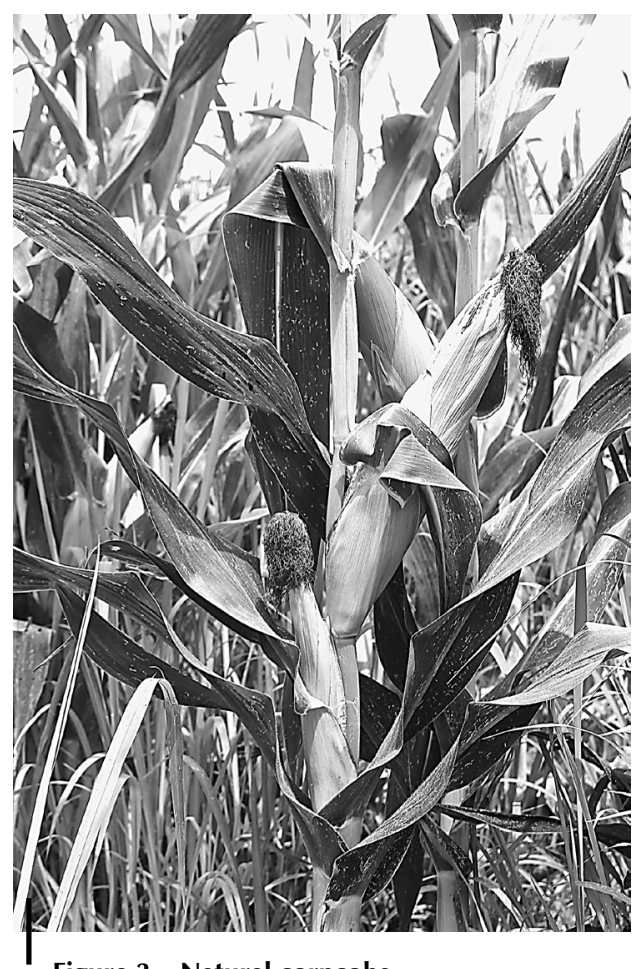

Figure 3 - Natural corncobs

(c) Ophelia Fischer, 2015

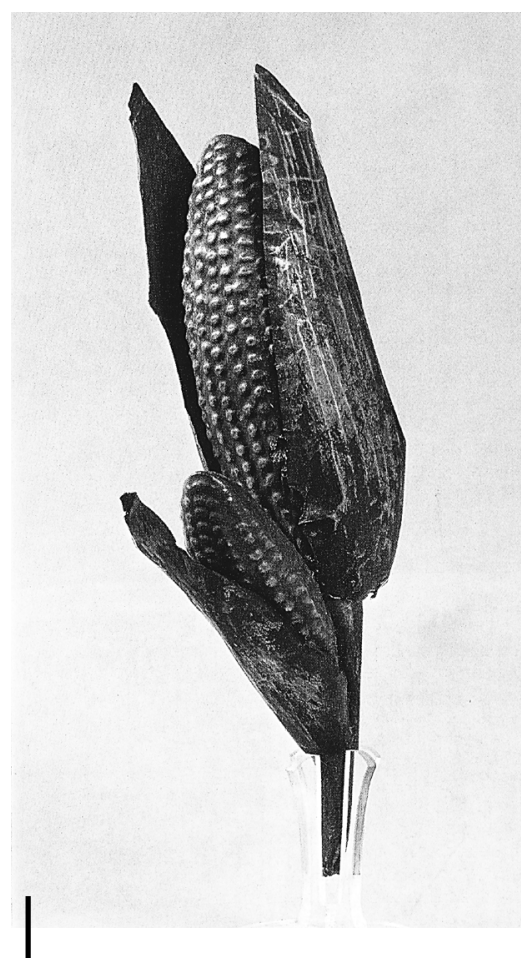

Figure 4 - First publication of the representation of the corncobs in "Alltag im alten Peru" by Hans Dietrich Disselhoff, 1966: 27

8 Hans Dietrich Disselhoff had been working at the Museum für Völkerkunde since 1936, from 1940 on as a curator, only interrupted by a stay after Second World War at the Museum für Völkerkunde in Munich. In 1954 he was appointed head of the department of the Americas and director of the museum until 1961. 
the exterior of the leaves and the stalk (Fig. 1)9. It remains unclear whether the yellowish/golden effect on the exterior leaves, caused by the application of a layer of lacquer, are due to the deposit conditions in the ground, or to an intentionally applied patina. The surface of the corncobs is darker, an effect which could be intentional or just due to the more difficult access for cleaning.

\section{ANALYTICAL RESULTS}

The analysis of the material undertaken at the Rathgen-Forschungslabor showed that the alloy contained no gold (cf. Table 1), but different proportions of silver and copper. Surprisingly, the eight sheets, which compose the object, two for each cob, two forming the big leaves, one for the small leaf and one making up the stem show different alloys (cf. Fig. 5).

The alloy and solder composition was probed by $\mu$ XRF analysis with an Artax Spectrometer (Bruker) with about $100 \mu \mathrm{m}$ spot size and a $30 \mathrm{~W}$ Mo-Tube. The Bruker MQuant fundamental parameter software was used for quantification. Despite the limitation of surface analysis of silver alloys, the surface $\mu \mathrm{XRF}$ showed some clear differences (Fig. 6). The large leaves and one part of the small cob have the same composition $(60-70 \% \mathrm{Ag}$, and $28-38 \%$ Cu in weight), while the large cob and one half of the small cob are made by sheets with a higher silver content (88$91 \mathrm{Ag}$, and $5-7 \% \mathrm{Cu}$ ), the stem shows a third alloy (81 $\mathrm{Ag}$, and $17 \% \mathrm{Cu}$ in weight)

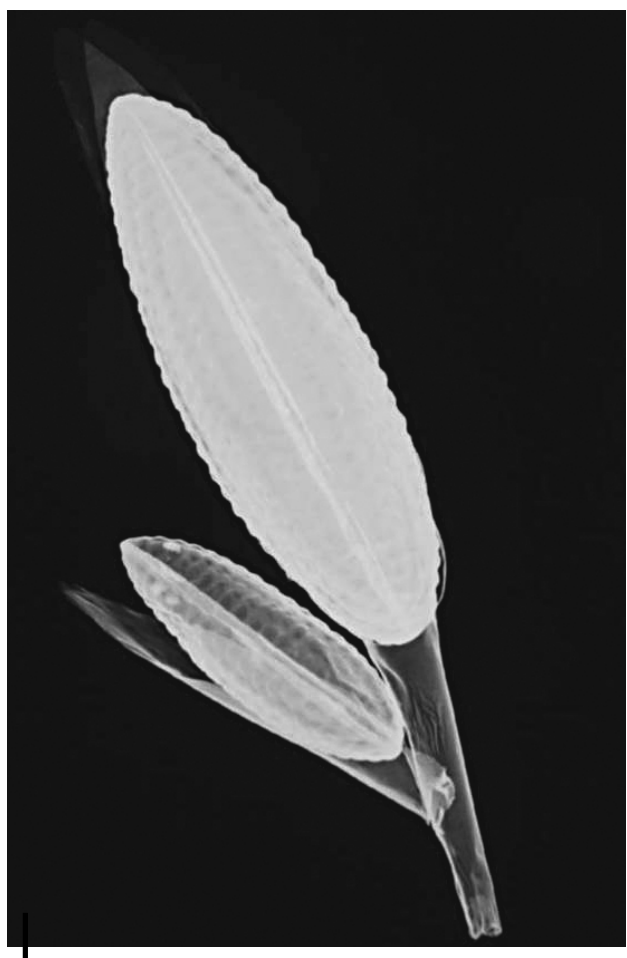

Figure 5 - X-ray plate of the representation of corncobs, Ethnologisches Museum, Staatliche Museen zu Berlin, SPK, V A 64430

Radiography: Hermann Born, Museum für Vorund Frühgeschichte, Staatliche Museen zu Berlin (cf. Table 1).

In the soldering spots a series of elements were detected in a low percentage like sulphur (S), iron (Fe), calcium (Ca), titanium (Ti), manganese (Mn), silicium (Si), and chlorine $(\mathrm{Cl})$, which could originate from surface contamination. However, there is zinc $(\mathrm{Zn})$ and copper $(\mathrm{Cu})$ in higher amounts compared to the metal sheets.

Zinc was only found in a higher percentage at the joint between the stem and the larger corncob: $7 \mathrm{wt} \%$ and $4.1 \mathrm{wt} \%$, respectively 10 (cf. Table 2 ). In other spots

9 Report Rathgen-Forschungslabor B-74_082812, 2.

10 Samples 74_2012_24_korn; 74_2012_25_korn. 

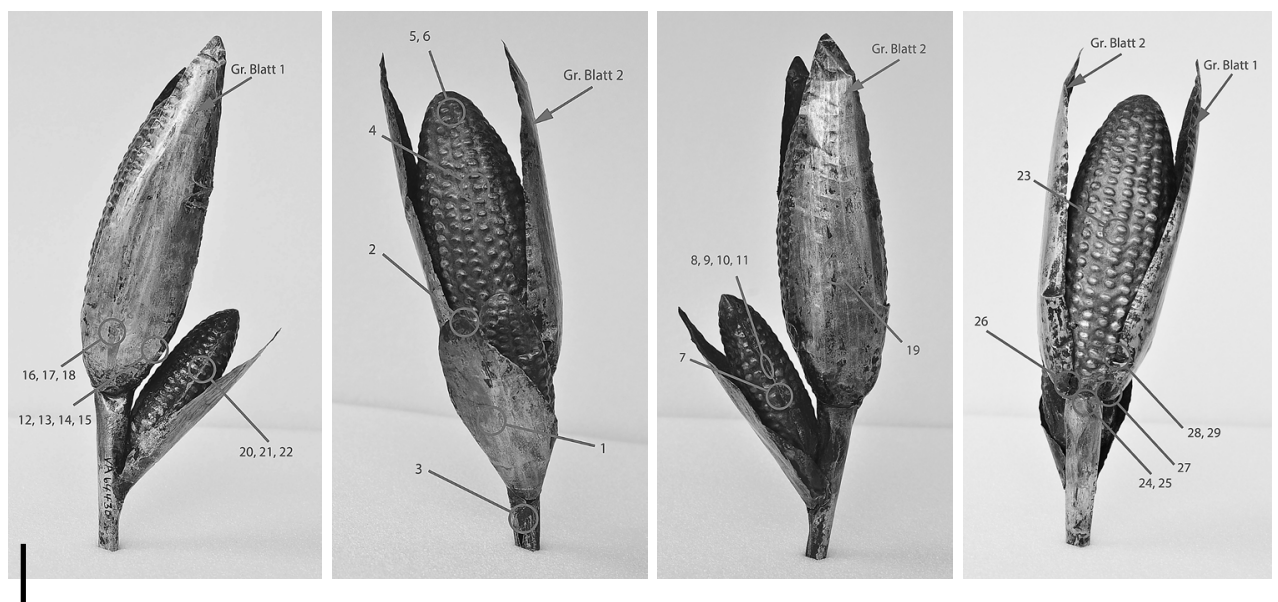

Figure 6 - Location of the samples

(C) Kai Engelhardt, 2017

Table 1 - Silver and copper concentrations in wt $\%$ obtained by $\mu$ XRF analysis for the representation of corncobs

Ethnologisches Museum, Staatliche Museen zu Berlin, SPK, V A 64430

\begin{tabular}{|l|c|c|}
\hline & $\mathrm{Ag}$ & $\mathrm{Cu}$ \\
\hline $\begin{array}{l}\text { 1. Large cob (both parts) and small cob } \\
\text { (on the side of the large cob) }\end{array}$ & $88-91$ & $5-7$ \\
\hline 2. Stem & 81 & 17 \\
\hline $\begin{array}{l}\text { 3. Small cob (side directed towards the } \\
\text { leaf) and large leafs 1 and 2 }\end{array}$ & $60-70$ & $28-38$ \\
\hline
\end{tabular}

measured at the joints of the corn cobs, the percentage of zinc is lower than $1 \mathrm{wt} \%$ (0.3-0.5 wt\%) ${ }^{11}$. Apparently zinc can appear occasionally in a low amount (up to $1.3 \mathrm{wt} \%$ ) in Chimú and Inca silver objects and has been found to a lesser content in copper and copper alloy objects and have to be interpreted as accidental inclusion (cf. e.g. a survey of the collection at the Museo de América, Madrid) (Rovira Lloréns \& Gómez Ramos, 1995: 21, cf. Table 1). To the knowledge of the authors there are no published analyses of Chimú and Inca solders for comparison. The analyses for the corncob solders up to $7 \mathrm{wt} \% \mathrm{Zn}$ seems high for an element which was introduces as an accidental inclusion and might be an indication of a modern solder which would match with the reconstructed history of the object 12 .

11 Samples 72_2012_8_Korn_kl; 72_2012_21_korn_kl; 72_2012_26_korn to 72_2012_29_korn.

12 The alloy of copper and zinc (brass) is introduced to the Americas in colonial times. Nevertheless zinc can appear in high percentages (up to $28 \%$ ) in some pre-Columbian bronzes, e.g. in early axes from Northwestern Argentina. A simultaneous melting of copper and zinc is not possible due to the different melting points (González, 2004: 142-143). No further data on pre-Columbian silver objects containing such high $\mathrm{Zn}$ contents is yet available. 
Table 2 - Composition in wt\% obtained by $\mu$ XRF analysis of the joining areas in the representation of the corncobs, Ethnologisches Museum, Staatliche Museen zu Berlin, SPK, V A 64430

These point analyses of un-cleaned surfaces from materials altered with time may not be representative of the composition of the initially used solder

\begin{tabular}{|l|l|c|c|c|c|c|c|}
\hline \multicolumn{1}{|c|}{ File name } & \multicolumn{1}{c|}{ Description } & S & Ca & Fe & Cu & Zn & Ag \\
\hline 74_2012_8_Korn_kl & Small corn cob, joint, "solder"? & 9 & 2 & 1 & 45 & 0.5 & 42 \\
\hline 74_2012_21_korn-kl & Small corn cob, joint, "solder"? & 13 & --- & 1 & 17 & 0.4 & 69 \\
\hline 74_2012_24_korn & Large corn cob/stem, joint, "solder" & 3 & 1 & 1 & 55 & 7.0 & 33 \\
\hline 74_2012_25_korn & Large corn cob/stem, "solder" & 6 & 1 & 1 & 49 & 4.1 & 40 \\
\hline 74_2012_26_korn & Large corn cob/sheet 2, "solder" & 9 & 3 & 11 & 2 & 0.3 & 71 \\
\hline 74_2012_27_korn & Large corn cob/sheet 1, "solder" & 1 & 1 & 1 & 50 & 0,2 & 45 \\
\hline 74_2012_28_korn & Large corn cob/sheet 1, "solder" & 7 & 7 & 11 & 6 & 0,3 & 63 \\
\hline 74_2012_29_korn & Large corn cob/sheet 1, "solder" & 8 & 5 & 9 & 5 & 0,2 & 68 \\
\hline
\end{tabular}

FTIR (Fourier transform infra-red analysis) and GC/MS (Gas chromatography-Mass spectrometry) was carried out on organic material. The FTIR analysis was carried out by a Typ Paragon 1000 PC (Perkin Elmer) in transmission by the use of a diamond cell. GCMS analyses were performed on a Perkin Elmer Clarus 500 (electron impact $70 \mathrm{eV}$, ion source temperature $230^{\circ} \mathrm{C}$, interface temperature $280^{\circ} \mathrm{C}$ ). The injection mode was splitless; the injector was kept at $280{ }^{\circ} \mathrm{C}$, and the helium gas flow-rate was $1.2 \mathrm{~mL} / \mathrm{min}$. Chromatographic separation was performed on a Perkin Elmer Elite $5 \mathrm{~ms}$ column (stationary phase: 5\% phenyl, 95\% methylpolysiloxane), with $0.25 \mathrm{~mm}$ internal diameter, $0.25 \mu \mathrm{m}$ film thickness and $30 \mathrm{~m}$ length. GC conditions: initial temperature $100{ }^{\circ} \mathrm{C}, 0.5 \mathrm{~min}$ isothermal, $15^{\circ} \mathrm{C} / \mathrm{min}$ up to $150{ }^{\circ} \mathrm{C}$, isothermal $1 \mathrm{~min}$, $7{ }^{\circ} \mathrm{C} / \mathrm{min}$ up to $300{ }^{\circ} \mathrm{C}$, isothermal $20 \mathrm{~min}$.

There are residues of different modern polymers, identified by FT-IR, which were applied more recently: a two component adhesive based on epoxy resin, (sample P2) and a transparent lacquer (sample P6), which contained methyl methacrylate (MMA)13.

The black substance at the bottom of the stem (sample P3) seems to be of organic nature. In the FT-IR analysis only weak bands in the C-H stretching region (2918, $2845 \mathrm{~cm}^{-1}$ ) and a very weak shoulder at $1734 \mathrm{~cm}^{1}$ indicate the presence of minor organic substances, the main component of the sample being of inorganic origin (quartz) ${ }^{14}$. GC/MS was used to verify if the sample could contain minor amounts

13 Report Rathgen-Forschungslabor B-74_082812, 14-21.

14 The IR-spectra of the samples were recorded by a Fourier-Transformation-Infrared-Spectroscopy (FTIR) and compared to the samples of the Rathgen-Forschungslabor and the IRUG databases. Report Rathgen-Forschungslabor B-74_082812, 11 
of tar, as its appearance seemed to be indicating. Besides modern materials (e.g. plasticizer), few triterpenoid resin markers were found but none of the European reference materials tested (tars of birch bark, pine or bones) gave a satisfactorily positive match for a tar or pitch. A similarity was found with tar made of bone material, which nevertheless would need to be systematically studied in order to be correctly interpreted. An unequivocal identification might be possible in the future if compared with the corresponding reference samples from South America could be achieved.

\section{THE ART DEALERS}

Both pieces, the one in Berlin as well as the one in Denver, are unique and similar in shape, size and the composition of the alloys (cf. Table 2, 3). As there are no similar objects known from archaeological contexts, it is quite possible that both of them came from the same workshop in Lima as Junius Bird proposed.

We only know that the Denver Art Museum bought their object from the Julius Carlebach gallery ${ }^{15}$, and Berlin bought theirs from Robert L. Stolper. The connection between the art dealers is easily explainable, as Robert Stolper, once he moved from Los Angeles to New York in 1961, installed his gallery at 1040 Madison Ave., a two minute walk around the corner from Carlebach's at East 80th Street, close to the Metropolitan Museum of Art.

Unfortunately, it is not yet possible to trace the provenances further back than to the galleries at the Upper East Side in New York. Nevertheless, it is possible that the first owner of both objects had been Julius Carlebach, who might have sold one of the representations of corncobs to Stolper, once Stolper arrived in New York. By this manner Stolper was able to offer it to his circle of clients in Europe, which did not overlap with Carlebach's, who mainly sold within the USA 16 . Julius Carlebach had gone into exile from Berlin to New York and was well known as the main provider of "primitive art" to Georg Gustav Heye, the founder of the Museum of the American Indian in New York17. Stolper however expanded in Europe where since the 1960s he had altering branches in different European cities, in Saint-Légier (Switzerland), Amsterdam, London, and Munich18.

15 "Carlebach Gallery in New York in 1960, as part of an object exchange", personal communication Margaret Young-Sánchez, the Denver Art Museum (email 4. 8. 2015).

16 Stolper accounted precisely the objects traded (Robert L. Stolper to Dieter Eisleb, letter from Amsterdam, 1. June 1965, where he asks for information lost "for my records".

17 Obituary on Julius Carlebach (Lübeck, 28. 7. 1909-New York, 13. 10. 1964) in The New York Times, 14. October 1964. Biography of Gustav Heye at the Smithsonian Institution: http://nmai.si.edu/ sites/1/files/pdf/press_releases/09-16-04_heye_biography.pdf

18 Adresses of Stolper Galleries of Primitive Art: Los Angeles 46, 1706 North Orange Grove Avenue Amsterdam, Lobo Braakensiekstraat 58; Villa La Raquette, Saint Légier, Vaud, Swizzerland (from 1965 on: ancient arts Itd with Morton Lipkin Representative); Archive Ethnologisches Museum Berlin: Amerikanische Archäologie. Erwerbungen 1 B- 1960-1965; 1 B- 1966-1969; 1 B- 1970-1978. 
Table 3 - Composition in wt \% of the corncobs representation from the Denver Art Museum (Exchange, 1960.64)

By Ed Raines, Fred Fraiker and Bruce Geller, Colorado School of Mines (CSM) in Golden, 25 April, 2012

\begin{tabular}{|c|c|c|c|c|c|c|c|c|}
\hline $\begin{array}{l}\text { No. of } \\
\text { sample }\end{array}$ & & $\mathrm{Fe}$ & $\mathrm{Ni}$ & $\mathrm{Cu}$ & $\mathrm{Zn}$ & $\mathrm{Pb}$ & $\mathrm{Ag}$ & Sn \\
\hline 1 & $\begin{array}{l}\text { Main corn, center of } \\
\text { kernel area }\end{array}$ & 0.24 & & 25.45 & 0.54 & 0.19 & 71.90 & 1.68 \\
\hline 2 & Outer leaf, large cob & 0.28 & & 27.86 & 0.44 & 0.17 & 69.69 & 1.56 \\
\hline 3 & $\begin{array}{l}\text { The stem of main stalk } \\
\text { (and seam?) }\end{array}$ & 0.43 & & 20.76 & 0.63 & 0.16 & 76.53 & 1.49 \\
\hline 4 & $\begin{array}{l}\text { Seam between two sides } \\
\text { of small ear of corn }\end{array}$ & 0.17 & 0.09 & 33.56 & 0.42 & 0.16 & 64.53 & 1.06 \\
\hline 5 & Inside of stem & 2.05 & & 26.35 & 0.50 & 0.15 & 69.56 & 1.39 \\
\hline 6 & Base stem & 0.78 & 0.11 & 22.85 & 0.36 & 0.13 & 74.57 & 1.20 \\
\hline 7 & $\begin{array}{l}\text { "wet" Fe corrosion on } \\
\text { stem }\end{array}$ & 11.25 & 0.09 & 22.33 & 0.25 & 0.15 & 64.43 & 1.49 \\
\hline 8 & $\begin{array}{l}\text { Seam at base of small } \\
\text { cob }\end{array}$ & 0.37 & & 30.63 & 0.44 & 0.11 & 68.45 & \\
\hline 9 & Inside hole in stem & & & 24.80 & & 0.20 & 75.00 & \\
\hline 10 & No sample & & & & & & & \\
\hline 11 & In between two stems & 1.62 & & 28.03 & 0.49 & 0.10 & 68.82 & 0.94 \\
\hline 12 & Blackest area on husk & & 0.14 & 23.56 & 0.38 & 0.21 & 73.90 & 1.81 \\
\hline 13 & $\begin{array}{l}\text { Inner leaf, inner edge - } \\
\text { green alteration }\end{array}$ & 0.17 & & 19.82 & 0.34 & 0.16 & 78.06 & 1.45 \\
\hline 14 & $\begin{array}{l}\text { worn area - bright edge } \\
\text { of leaf }\end{array}$ & 0.56 & & 29.97 & & 0.14 & 69.32 & \\
\hline 15 & $\begin{array}{l}\text { "Yellowish" area - inner } \\
\text { leaf of small cob }\end{array}$ & & 0.17 & 22.47 & 0.43 & 0.14 & 75.62 & 1.16 \\
\hline
\end{tabular}

The 1960s were heydays on the art market. Due to the economic highpoint combined with the awareness of damages suffered in Second World War, German museums spend a lot to compensate the losses, either those in objects as well as those in reputation and relationships with the international community. The construction of a new building for the Museum für Völkerkunde in Berlin-Dahlem, which opened in 1970, was the background for "completing" the collections (Westphal-Hellbusch, 1973). From Stolper the Museum für Völkerkunde bought 279 ethnographic objects from different parts of the world: Africa, India, south East Asia and Australia; over half — 195 objects— originate from the Americas. 
Between 1960 and 1983, 79 pre-Columbian pieces were bought for the sum of 423.245 DM, with several acquisitions every year. A ceremonial knife (tumi) from Lambayeque (Peru) was bought from the Stolper Gallery in 1966 for the amount of 54.000 DM (Fig. 7).

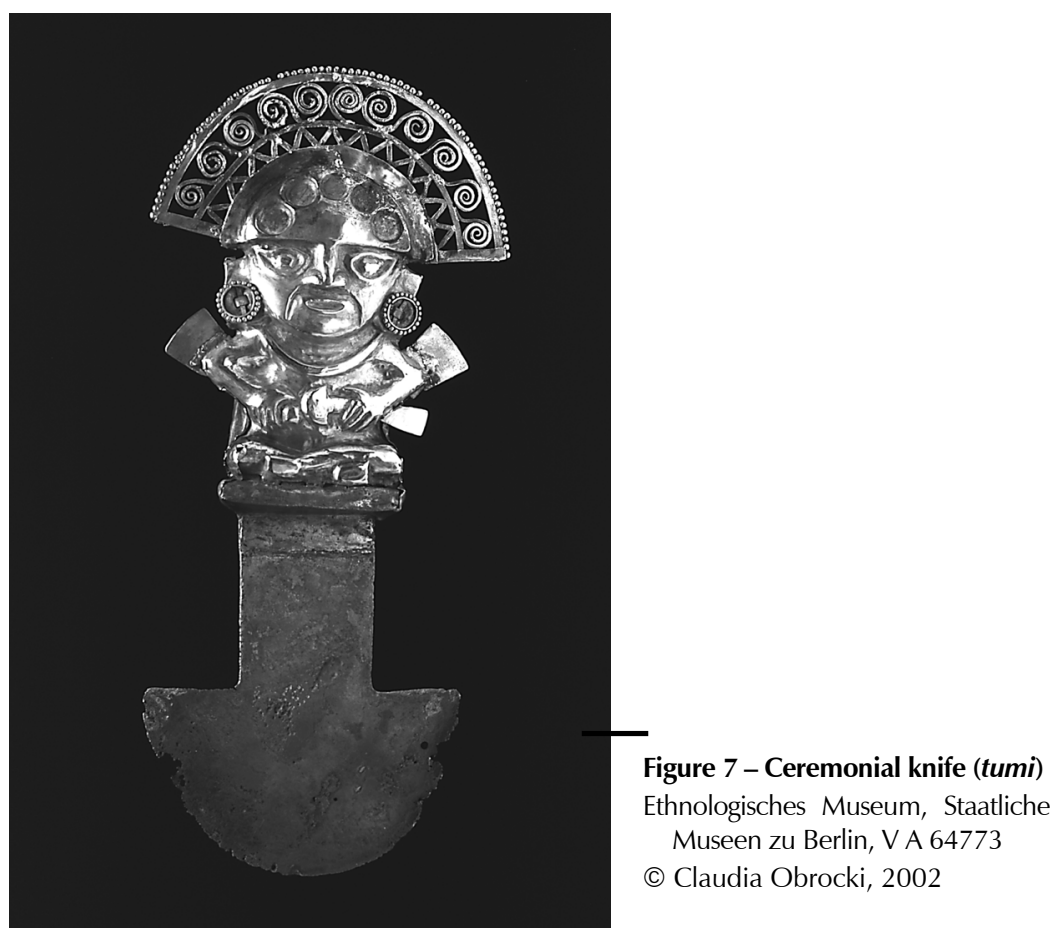

As a selling technique Robert Stolper deposited objects he wanted to be purchased in one of the museums he was related to and waited until the annual budget was released and the objects could be bought. In the meantime, he maintained an active personal correspondence with the respective museums curators ${ }^{19}$. In some cases the purchased objects were even exchanged by the museums with objects taken from the historical collections.

However, not all the artworks Stolper offered were trustworthy. One of the early acquisitions from the Stolper Gallery at the museum in Berlin, a stucco head supposedly related to Palenque, turned out to be a fake (Gaida, 2014).

The very euphoric assessment of the stucco head -it was compared to the bust of Nefertiti- soon was questioned by Gordon Ekholm, curator for Mexico and Central America at the Museum of Natural History in New York20. At the

\footnotetext{
19 Archive Ethnologisches Museum, Amerikanische Archäologie, Erwerbungen, 1 B 1960-1965; 19661969.

20 Two more stucco heads offered to the Etnografisk Samling in Copenhagen, were declined.
} 


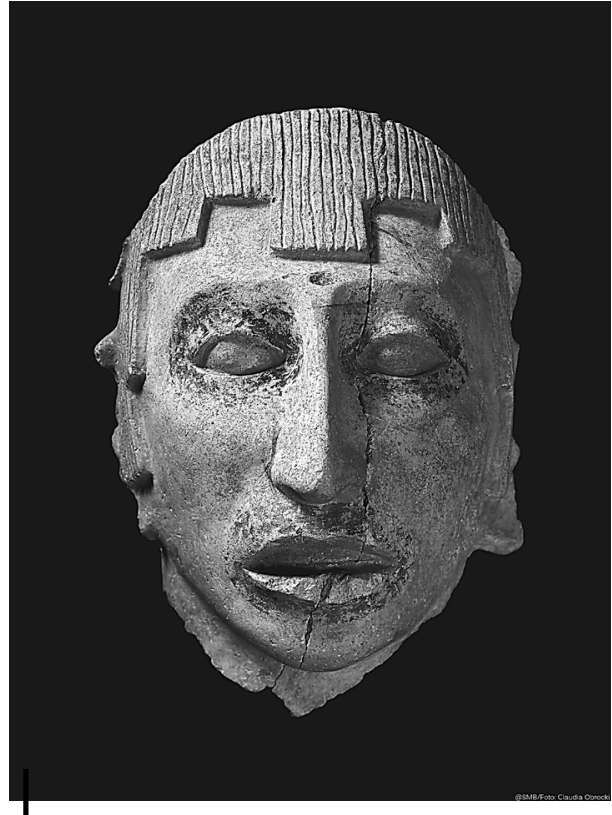

Figure 8 - False "Maya" stucco head

Ethnologisches Museum, Staatliche Museen zu Berlin, PK, IV Ca 44330

(C) Claudia Obrocki, 2007
International Congress of Americanists in Spain 1964, Dieter Eisleb, then curator at the Department of American Archaeology and Gordon Ekholm agreed upon the examination of the stucco head (Fig. 8). The analysis made by Ekholm showed a high amount of calcium sulphate in the stucco head (not usual in Palenque stucco samples), and even a fresh hair of a domesticated pig. When confronted with the result, Stolper immediately offered a replacement for the fake. The curators in Berlin chose a Huaxtec Stela in exchange and maintained the relationship for 20 more years.

This is not the only case where Robert Stolper was involved in deals of artworks, which turned out to be fakes. A particularly brazen case is the "Mesoamerican human skull decorated with turquoise mosaic" sold by Stolper to the National Museum of Ethnology in Leiden (the Netherlands). Martin Berger found out that there were ten similar pieces in different museums and private collections (Berger, 2013). The skull at the Museum in Leiden was also bought in the 1960s, nearly at the same time as the Berlin silver corncobs, and also appealed to curators because of its uniqueness. By that time, in 1963, there were little archaeological contexts available (with exception of tomb 7 at Monte Alban (Caso, 1932)). Nevertheless several scholars soon concluded that these skulls might not be complete fakes, but a modern combination of pre-Columbian elements 21 . The analysis carried out by the Centre de Recherche et de Restauration des Musées de France in Paris in 2011 and 2012 confirmed the hypothesis, the skulls being composites, made out of pre-Columbian elements put together in a way that, as Berger puts it, they "fit the style" 22 .

As far as the representation of corncobs is concerned, it might be a similar type of fake. Putting together the pieces of the puzzle there is (1) the iconography,

21 Ekholm, 1983 (letter to Ellen C. Hvatum Werner, dated 13.12.1983, on file at the DeYoung Museum), cited by Berger, 2013: 18; Urcid, 2010.

22 The skull was suggested to be pre-Columbian from the Mixtec area, and the turquoises and shells typical for the Post classic period. The concretions (hydroxylapatite) at some of the shell inlays nevertheless only attach if lying for a long time in the ground. The attachment of one of the mosaics was made with the usual pre-Columbian glue (copal, bee wax, etc.). All of them showed modern glues: modern household glue (Duco cement) at the Dumbarton Oaks piece, or shellac originating from Asia (at the skull in Marseille) (Berger, 2013: 28). 
which has not been reported in any archaeological context, and (2) the different compositions of the alloys (cf. Table 1), which could be a hint to the reuse of pre-Columbian silver sheets from originally different contexts. Particularly cups (aquillas) made of silver sheets, often found in bad conditions in archaeological contexts, could easily be reshaped and assembled. This would also explain (3) the different modern glues and "solders" containing a higher percentage of Zinc in the joints (cf. Table 2). With the alleged provenance "Chimú" it would —as Martin Berger proposed for the mosaic sculls- "fit the style", here of pre-Columbian metalwork from the North coast of Peru in the Late Intermediate Period and Late Horizon (1200-1532 AD).

On the strategies of placing so-called "primitive art" on the art market after Second World War little has been studied yet23. The criminal energy inverted by some of the art dealers and the willingness of collectors and museums curators to ignore suspicions in favor of unique artwork for their collections is a field highly worthy of our attention.

\section{Acknowledgments}

This study was initiated by the interest and persistence of Andrew Hamilton, who brought in contact the museums staffs of the Ethnologisches Museum in Berlin, the Denver Art Museum in Denver and the Mint Museum in Charlotte. Andrew Hamilton also guided the research of the laboratories and shared generously the archival documents he had recovered with those involved in the project.

At the Denver Art Museum we are very much obliged to Margaret Young-Sánchez, who provided us with illustrations and information about the analysis of the Denver object. At the Denver Art Museum the analysis was coordinated by the senior objects conservator Gina Laurin and realized at the Laboratory of the Colorado School of Mines in Golden by Ed Raines, Bruce Geller, and Fred Fraiker. Jonathan Stuhlman, curator at the Mint Museum in Charlotte kindly checked the provenance of the golden corncob in their collection. To confirm the selling strategies of the art dealer Robert L. Stolper in different museums in Europe, Esther Tisa, in charge of the provenance research at the Museum Rietberg in Zurich, was so kind to provide us with transcriptions of the correspondence between the Museum Rietberg and Robert L. Stolper. The transcriptions were done by Pierre-Louis Blanchard. The research of Martin Berger on Robert L. Stolper and the unscrupulous art market in the 1960s made possible to fit the pieces of the puzzle together. Last but not least we are obliged to Paz Nuñez-Regueiro and Maria-Filomena Guerra who by their interest made this paper possible. Many thanks, to all of them.

${ }^{23}$ Cf. Radnóti, 1999; Bruhns \& Kelker, 2010; Kelker \& Bruhns, 2010; Jones, 1992; Dagen \& Murphy, 2013. 


\section{Unpublished documents}

Archive Ethnologisches Museum, Berlin: Amerikanische Archäologie. Erwerbungen 1 B1960-1965; 1 B- 1966-1969; 1 B- 1970-1978

Archive Denver Art Museum

Report Rathgen-Forschungslabor B-74_082812

\section{Cited references}

BERGER, M. E., 2013 - Real, Fake or a Combination? Examining the Authenticity of a Mesoamerican Mosaic Skull. In: Creating Authenticity. Authentication Processes in Ethnographic Museums (A. Geurds \& L. Van Broekhoven, eds.): 11-37; Leiden: Sidestone Press.

BRUHNS, K. \& KELKER, N. L., 2010 - Faking the ancient Andes, 220 pp.; California: Left Coast Press.

CASO, A., 1932 - Monte Albán, richest archaeological find in the Americas. National Geographic Magazine, 62: 487-512.

CORDY-COLLINS, A., 1996 - Chimú. In: Andean Art at Dumbarton Oaks, vol. 1 (E. H. Boone, ed.): 223-276; Washington, D.C.: Dumbarton Oaks Research Library and Collection.

DAGEN, P. \& MURPHY, M., 2013 - Charles Ratton: I'invention des arts "primitifs", 183 pp.; Paris: Skira Flammarion, musée du quai Branly.

DISSELHOFF, H. D., 1961a - Neuerwerbungen mexikanischer Altertümer. Baessler-Archiv, N. F., 9: 5-7.

DISSELHOFF, H. D., 1961b - Das Berliner Museum für Völkerkunde gestern und morgen. Baessler-Archiv, N. F., 9: 193-216.

DISSELHOFF, H. D., 1966 - Alltag im alten Peru, 155 pp.; München: Callwey.

DISSELHOFF, H. D., 1967 - Daily Life in Ancient Peru, 155 pp.; New York: McGraw-Hill Book Company.

GAIDA, M., 2014 - Real or Fake? German Post-War Nationalism and the forged Maya Stucco Head in the Ethnologisches Museum. Ixiptla, 1: 77-89.

GONZÁLEZ, L. R., 2004 - Bronces sin nombre. La metalurgia prehispánica en el noroeste argentino, 432 pp.; Buenos Aires: Fundación CEPPA.

HOWARD, C., 1968 - Pizarro and the Conquest of Peru, 153 pp.; New York: American Heritage Pub. Co., Harper \& Row.

JONES, M., 1992 - Why fakes matter: essays on problems of authenticity, 198 pp.; London: British Museum Press.

KELKER, N. L. \& BRUHNS, K., 2010 - Faking Ancient Mesoamerica, 256 pp.; California: Left Coast Press.

RADNÓTI, S., 1999 - The fake: forgery and its place in art, x + 245 pp.; Lanham: Rowman \& Littlefield.

ROVIRA LLORÉNS, S. \& GÓMEZ RAMOS, P., 1995 - Los objetos de metal de la colección Juan Larrea: un estudio arqueometalúrgico. Anales del Museo de América, 3: 21-33.

URCID, J., 2010 - Human skulls with mosaic designs. In: Ancient Mexican Art at Dumbarton Oaks (S. Toby Evans, ed.): 185-190; Washington, D. C.: Dumbarton Oaks. 
Product of the art market? The representation of silver corncobs at the Ethnologisches Museum in Berlin

WESTPHAL-HELLBUSCH, S., 1973 - Hundert Jahre Museum für Völkerkunde Berlin. Zur Geschichte des Museums. Baessler-Archiv, N. F., XXI: 1-99. 